This item was submitted to Loughborough's Research Repository by the author.

Items in Figshare are protected by copyright, with all rights reserved, unless otherwise indicated.

\title{
Better off at home? Rethinking responses to trafficked West African footballers in Europe
}

PLEASE CITE THE PUBLISHED VERSION

http://dx.doi.org/10.1080/1369183X.2014.927733

PUBLISHER

(c) The Author(s). Published by Taylor \& Francis.

\section{VERSION}

VoR (Version of Record)

\section{PUBLISHER STATEMENT}

This work is made available according to the conditions of the Creative Commons Attribution 4.0 International (CC BY 4.0) licence. Full details of this licence are available at: http://creativecommons.org/licenses/ by/4.0/

\section{LICENCE}

CC BY-NC-ND 4.0

\section{REPOSITORY RECORD}

Esson, James. 2019. "Better Off at Home? Rethinking Responses to Trafficked West African Footballers in Europe". figshare. https://hdl.handle.net/2134/17413. 
This article was downloaded by: [Loughborough University]

On: 20 August 2015, At: 07:53

Publisher: Routledge

Informa Ltd Registered in England and Wales Registered Number: 1072954 Registered

office: 5 Howick Place, London, SW1P 1WG

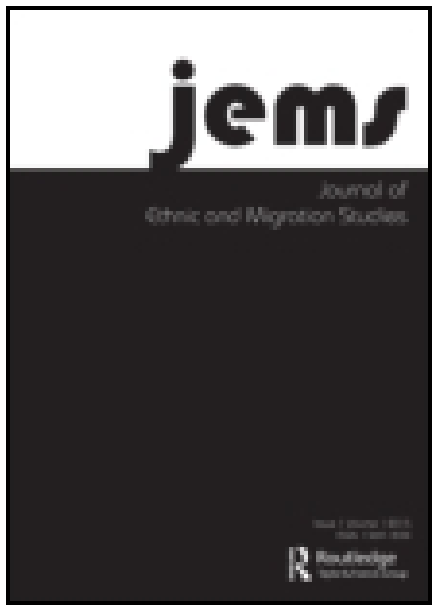

\section{J ournal of Ethnic and Migration Studies}

Publication details, including instructions for authors and subscription information:

http:// www.tandfonline.com/loi/ cjms20

\section{Better Off at Home? Rethinking Responses to Trafficked West African Footballers in Europe}

J ames Esson

Published online: 17 J un 2014.

\section{CrossMark}

$\underline{\text { Click for updates }}$

To cite this article: J ames Esson (2015) Better Off at Home? Rethinking Responses to Trafficked West African Footballers in Europe, Journal of Ethnic and Migration Studies, 41:3, 512-530, DOI: 10.1080/1369183X.2014.927733

To link to this article: http:// dx.doi.org/10.1080/1369183X.2014.927733

\section{PLEASE SCROLL DOWN FOR ARTICLE}

Taylor \& Francis makes every effort to ensure the accuracy of all the information (the "Content") contained in the publications on our platform. Taylor \& Francis, our agents, and our licensors make no representations or warranties whatsoever as to the accuracy, completeness, or suitability for any purpose of the Content. Versions of published Taylor \& Francis and Routledge Open articles and Taylor \& Francis and Routledge Open Select articles posted to institutional or subject repositories or any other third-party website are without warranty from Taylor \& Francis of any kind, either expressed or implied, including, but not limited to, warranties of merchantability, fitness for a particular purpose, or non-infringement. Any opinions and views expressed in this article are the opinions and views of the authors, and are not the views of or endorsed by Taylor \& Francis. The accuracy of the Content should not be relied upon and should be independently verified with primary sources of information. Taylor \& Francis shall not be liable for any losses, actions, claims, proceedings, demands, costs, expenses, damages, and other liabilities whatsoever or howsoever caused arising directly or indirectly in connection with, in relation to or arising out of the use of the Content. 
This article may be used for research, teaching, and private study purposes. Terms \& Conditions of access and use can be found at http://www.tandfonline.com/page/termsand-conditions

It is essential that you check the license status of any given Open and Open Select article to confirm conditions of access and use. 


\title{
Better Off at Home? Rethinking Responses to Trafficked West African Footballers in Europe
}

\author{
James Esson
}

The association between the football industry and the trafficking of West African youth has captivated academic, media and political interest. This article uses football trafficking as a case study to think through the broader conception of mobile African male bodies in football migration and trafficking discourses. I contribute to and move beyond existing literature on African football migration by stepping away from structural approaches currently used to conceptualise this migratory process. This is achieved by bringing migrants' subjectivities to the fore, and in doing so I also provide a novel critique of policy responses to irregular football migration. The article draws on data obtained from migrants who left West Africa for Europe, exploring the journeys these would-be footballers took, and their trajectories and circumstances after arrival. The central argument is that existing policy responses frame irregular football migrants as being 'better off at home'. Problematically this creates a tension as for many of these migrants their country of origin is precisely where they do not want to be. Consequently, many remain in destination countries illegally without any means of subsistence.

Keywords: African Youth; Agency; Football Trafficking; Irregular Migrants

\section{Introduction}

In May 2008, a fish trawler abandoned by its captain was found off the shore of Tenerife. Regrettably, the contents were not of the aquatic variety. The cargo consisted of approximately 130 West African males suffering hypothermia and dehydration (McDougall 2008). The last decade has witnessed increasing numbers of African migrants attempting to enter Europe via unauthorised journeys across the Mediterranean Sea and the Atlantic Ocean (Hernández-Carretero and Carling 2012). Yet what made the above incident particularly newsworthy was the discovery that several

James Esson is an Assistant Lecturer at the Department of Geography, University College London, London, UK. Correspondence to: Department of Geography, University College London, 26 Bedford Way, London WC1H 0AP, UK. E-mail: james.esson.09@ucl.ac.uk 
of the survivors found onboard were teenagers erroneously embarking on a journey they believed would lead to football contracts with Real Madrid or Marseille (McDougall 2008). Concern regarding irregular migration within the football industry was highlighted almost a decade earlier in a 1999 United Nations High Commissioner for Refugees (UNHCR) report. The report concluded by highlighting the 'danger of effectively creating a modern day slave trade in young African footballers' (cited in Bale 2004, 240). Similar arguments were made a decade later in the European Commission's Study on Sport (ECS), which claimed that increasing numbers of young West African males are undertaking clandestine journeys to Europe under the false pretence of a contract or trial with a professional football club (ECS 2009).

It is estimated that since 2005 there have been more than 1000 cases of footballrelated irregular migration in Paris alone (Poli 2010a) and approximately 7000 across France (Sparre 2007). These figures are from the organisation Culture Foot Solidaire (CFS), which is based in Paris and was founded in 2001 by Jean-Claude Mbvoumin, a former Cameroonian international player. CFS aims to support young African players allegedly trafficked or unsuccessful in their trials with European football clubs. As with all statistics, particularly those concerning 'hidden populations', that is, members of society who may be associated with illegal or stigmatised activities (Tyldum and Brunovskis 2005), these figures should be treated with caution. Nevertheless, regarding the cases in Paris, CFS claims that $98 \%$ are illegal immigrants and $70 \%$ are under the age of 18 .

There are currently two main policy responses to irregular football migration. The first argues for stronger regulation of international transfers between football clubs. The second proposes that raising awareness in origin countries will reduce instances of West African youth falling foul of scams. Alongside these policy responses, leading figures at football associations, human rights groups and sections of the liberal European press, claim that the underdevelopment of African football or its 'culture of mediocrity' pushes African players to ply their trade outside of the continent (Darby, Akindes, and Kirwin 2007). Proponents of the 'culture of mediocrity' argument contend that improving the standards of African football will encourage players to stay in Africa.

This article uses irregular football migration as a case study to think through the broader conception of mobile African male bodies in football migration and trafficking discourses. I contribute to and move beyond existing literature on African football migration by stepping away from structural approaches currently used to conceptualise this migratory process, namely dependency and world systems theory (see Carter 2013 for an overview). These top-down accounts are able to paint a basic picture of migratory patterns; however, they also create a scenario whereby migrants are construed as responding mechanically to structural forces beyond their control. I avoid this shortcoming by bringing the subjectivities of African migrants to the fore. By doing so, I draw attention to the increasingly spatial nature of approaches used by young West Africans to overcome the uncertainty and constraints on life ambitions facing them in Africa (see also Ferguson 2006; Langevang and Gough 2009), and how 


\section{J. Esson}

this connects to the issue of football trafficking. This also enables me to further debates over migrant agency, particularly research problematising perceptions of migrants as objects or victims of migration regimes (see Anderson, Sharma, and Wright 2009; Sharma 2003).

The article draws on five focus groups (19 individuals in total) and in-depth interviews (10 in total) conducted in Paris during three consecutive months of fieldwork in 2011. Participants were obtained through CFS and consisted of Guinean, Ivorian and Cameroonian youth who had been involved in irregular football migration. To complement the formal interviews, I was informed by CFS of an informal football club for irregular football migrants. The club was located in Bel-Air and trained 2-3 times a week. ${ }^{1}$ I was allowed to have informal conversations with people at the club, which averaged just over 30 players per session. CFS is also closely linked to professional football players, and it was hoped that this would provide a means to conduct interviews with successful football migrants and contact clubs in the junior sector of European football. Unfortunately, perhaps due to the nature of the topic, CFS was unable to facilitate a meeting with these individuals. Additionally, although the article focuses on irregular football migrants in European destination countries, I also make reference to insights gained from data collected in Accra as part of seven consecutive months of fieldwork in 2011.

I begin the article by providing an overview of the irregular football migration process and by examining the first main policy response (regulation of clubs). I then bring insights obtained from participants in Paris and Accra into conversation with debates over the agency of irregular migrants and literature on cultural meanings of mobility in sub-Saharan Africa. I highlight the treatment of irregular football migrants in Paris, followed by a critique of the second main policy response (anti-trafficking campaigns) and the 'culture of mediocrity' argument. I tie the different sections of the article together by showing that while responses to irregular football migration appear distinct, they are connected by a sedentary bias nestling in the implicit assumption that had it not been for some form of football-related intervention, irregular football migrants would have preferred to remain in their countries of origin. I argue that this creates a tension, because policy responses advocating that these young West African males should seek their future in situ are diametrically opposed to their migratory disposition, which associates spatial mobility with social mobility.

\section{Football Trafficking}

The association between the football industry and the irregular migration of West African youth has captivated academic, media and political interest (Bennhold 2006; Poli 2010b; Scherrens 2007). Michel Platini, former French international and current President of the Union of European Football Associations (UEFA), highlighted the concern regarding this association amongst leading figures governing professional football: 
Today, in the world and in Europe, there is trafficking of children. I will not mince my words because the situation is serious. What else do you call a phenomenon whereby children aged 12 or 13 are torn away from their environment and culture to join a business in return for payment? This is what is happening in football. (UEFA 2008).

This notion that migration through football can reduce an individual's autonomy and lead to exploitative practices is best grasped through a real-life example. The case of Gerard, a 16-year-old Guinean migrant now living in Paris, contains nuances unique to his personal situation and background, however his trajectory to Europe typifies that of other migrants, thus making it a good vignette to bring the migratory process to life.

\section{Gerard's Story}

I was first seen playing for my neighbourhood team ... there is a championship at the end of each season and scouts from the Star of Guinea saw me and asked me to play there as a reserve. Eventually I got to play for the [REDACATED] and it was during a league game when the agent found me and said he wanted to take me to Europe ... $\mathrm{He}$ (agent) went to my uncle because my mother is ill and my parents divorced when I was a young child, and so my uncle is head of the family... He (uncle) also knows about football so the agent talked to him and made the deal ... He (uncle) played football when he was younger and when he was playing he was able to take care of the whole family ... I wanted to be the next one in the family to be able to do that (support the family) and my mother and my uncle were also hoping that I could do the same so they had to take up this chance. ... My uncle never thought the agent would fuck us over like this!

My mother ended up selling most of the family land to pay to send me to Europe ... They paid the agent $€ 3,500$ plus $€ 1,000$ as pocket money ... he said it was for the plane tickets and everything ... When I first came it wasn't Paris proper I was in the suburbs, the agent put me in a hotel and he would come and visit everyday to make sure I was okay. The room was in his (agents) name and ... [He had] my passport, my papers from the football federation in Guinea, papers from my education and my pocket money, everything. The agent told me that on January 14th I was going to Lyon to try out for some academies but after the 13th he stopped coming. I waited through to the night of the 17th and when the agent didn't come the manager of the hotel said I had to go. ${ }^{2}$

Gerard's account draws attention to many of the key practices that take place during the irregular football migration process as illustrated in the step-by-step summary below, which was formulated using secondary sources ${ }^{3}$ and primary data outlined above.

(1) An intermediary purporting to be a football agent or talent scout identifies a player in West Africa at a match, trial or 'Justify' and offers him the opportunity to be recruited by a foreign club. An important and key finding in this research is that the intermediary does not have to physically meet the player. The Internet now provides opportunities to recruit players remotely. 
(2) The intermediary not only asks the player for money in exchange for securing this opportunity akin to a 'finders fee' but also to cover costs such as travel to and accommodation in the destination country. The player's immediate and extended family often sell family possessions, remove siblings from schooling or take out a loan to meet the costs, which is typically $€ 3000-5000$.

(3) The player arrives in a destination country, in most cases with a one-month tourist visa. Contrary to popular media coverage the travel conditions are not always illegal and dangerous. Players often arrive using legal channels, and in the instances where they do not it is often through traditional modes of transportation with false travel documents. On arrival, the intermediary often takes the player's documents and any spending money for 'safe keeping'.

(4) While in a destination country the player may or may not attend a trial with a club. In some cases, he may be taken to multiple trials in different countries as part of a group until a contract is offered and the agent is satisfied with the terms.

(5) If the trials are successful, the player signs a contract with the club. However, in some cases, the contract is of an insecure nature with unfavourable financial terms enabling the intermediary to earn a commission from facilitating multiple transfers.

(6) If the player is unsuccessful at his trials or his contract is not renewed and another one cannot be found, the intermediary abandons him, often taking the player's documentation and any remaining money with him. Once the precarious nature of his situation is realised, the player is often too ashamed to return home and remains in the destination country illegally without any means of subsistence.

\section{Trafficking in Football and Trafficking through Football}

The migratory process outlined above appears to comply with the definition of trafficking as outlined in the Palermo Protocol. It features an act such as the recruitment and transportation of others, which is followed by the methods used to enforce those act(s), such as threat, the use of force, fraud, coercion or other abuses of power or of a position of vulnerability. It then relates to a motive, that is, to obtain financial gains through exploitation. In some extremely rare cases, after handing over money to an intermediary, the players do indeed procure contracts or trials with clubs, albeit of an exploitative nature. This is referred to as 'trafficking in football' (Poli 2010b). However in the vast majority of cases, the alleged interest from a foreign club is a charade, and once in the destination country and having appropriated his 'fees' the intermediary abandons the player. This is known as 'trafficking through football'. Both forms of migration are frequently conflated under the umbrella term 'football trafficking' (Poli 2010b). It is also important to note that football trafficking is not only an irregular migratory process because it includes people who enter a country without the proper authority; people who remain in a country in contravention of their authority; people moved by migrant smugglers or human trafficking' 
(Koser 2010, 183), but it also irregular within the regulatory context of international football transfers.

Football trafficking contravenes regulations outlined by International Federation of Association Football (FIFA) in its 'Regulations for Players Agents' (RPA) and 'Regulations on the Status and Transfer of Players' (RSTP). For example, 'players' agents' activity may only be carried out by natural persons who are licensed by the relevant association to carry out such activity' (FIFA 2008). Yet the vast majority of football trafficking cases involve intermediaries who do not hold a licence but attempt to perform the role of an agent (see also Lindberg 2006). Moreover, with the exception of the following three rules, international transfers are not permitted if a player is a minor (under the age of 18); (i) a player's parents move to the country in which the new club is located for non-football-related reasons; (ii) the transfer takes place within the territory of the European Union or European Economic Area, the player is aged between 16 and 18, and the receiving club ensures the player is provided with a football education equivalent to the national standard alongside optimum living standards; and (iii) the player lives no further than $50 \mathrm{~km}$ from a national border and the club with which the player wishes to be registered in the neighbouring association is also within $50 \mathrm{~km}$ of that border (FIFA 2010, 20).

\section{Policy Responses}

As indicated in quote above, UEFA have publicly voiced their concerns about the irregular migration of young African footballers, as have senior members of the Confederation of African Football (CAF). In March 2001, FIFA President Joseph Sepp Blatter attempted to move beyond his previous criticisms of the issue, which were deemed political rhetoric, by implementing changes to the RSTP. As mentioned above, FIFA introduced sanctions and regulations to 'protect the human rights of minors' by restricting clubs from buying and signing players under the age of $18^{4}$ (FIFA 2010). Additionally, a regulatory measure known as the 'Transfer Matching System' (TMS) was introduced in 2008. This is a web-based data information system designed to simplify and improve the transparency of transfer information, and keep a record of a player's biographical data (FIFA 2013). When two clubs undertake a transfer they have to enter identical information into the system and meet the statutes outlined in FIFA's RSTP, otherwise the transfer will be blocked by FIFA and an 'International Transfer Certificate' (ITS) will not be given (FIFA 2013). African football associations have been particularly keen to understand and make use of the new system (FIFA 2011).

Alongside these approaches, an alternative strategy is provided by CFS, which seeks to reduce cases of irregular football migration by altering the practices of clubs through the promotion of an 'Ethical Transfer Charter'. The Ethical Transfer Charter operates in a manner akin to fair trade agreements for products such as coffee and diamonds, as clubs that sign up would agree to only sign minors who had been 'ethically sourced'. 5 Both of the policy responses outlined above are attempting to target the demand for young West African players at the institutional level, and 
vicariously, trafficking in football. In many ways this makes sense, as it is easier to regulate identifiable institutions than track down and regulate intermediaries posing as agents. Yet Anderson and Andrijasevic (2008) note that campaigns and regulations targeting the 'demand' for trafficked persons have two potential recipients for their strategy, the consumers of goods and services produced or performed by trafficked people (in this case football fans, TV broadcasters and sponsors) and the employers or labour users of trafficked people (football clubs). They argue that the difficulty with this approach is that we cannot target employer demand for trafficked labour per se, nor consumer demand for goods or services produced or performed by trafficked people (Anderson and Andrijasevic 2008).

It is possible that demand does indeed exist within and beyond the football industry for cheap and exploitable labour that undercuts minimum labour standards, and that this could correlate with a demand for young foreign nationals because they are easier to control (see Alegi 2010; Poli 2010a). Yet this does not mean clubs equate their need for cheaper labour with a need for trafficked labour. It is therefore also possible that there are few willing signatories to the 'Ethical Transfer Charter' and scant recognition of FIFA regulations, because clubs see no need in agreeing to stop engaging in player trafficking if they do not consider themselves involved in this activity to begin with. Robert, a 23-year-old Cameroonian, stressed this point when discussing his experiences with a German Bundesliga team, where problems arose for him and four fellow trialists because the club attempted to act appropriately and in the players' best interests:

\begin{abstract}
He (agent) got us the trial at [REDACTED], we got there and there was an argument between the agent and the club. The agent wanted the club to sign us without our parent's involvement but we were under age, you understand? All of these professional clubs, when you take a kid like that and they want to sign you, they want to make sure that the parents are involved and have signed the correct documents. They want to see that everything is well taken care of.... So that is the thing he has to run away because there was no way he was going to take us back to Cameroon, so along the line things broke down and the agent ran away and we were abandoned in a hotel. ${ }^{6}$
\end{abstract}

\title{
New Crimes and New Victims
}

The main concern of irregular football migrants was not the practices of clubs (associated with trafficking in football). Instead, their concern was treatment by immigration officials and social services in destination countries following instances of trafficking through football. This is in many ways linked to the manner in which football trafficking has been brought to public policy attention as a pressing new social problem. The above quotes from CFS and FIFA show that football trafficking matches Best's (1999) general model of the social and political construction of new crimes and new victims (O'Connell Davidson 2011).

Best (1999) argued that in order for a given phenomenon to be acknowledged and treated as a grave and imminent problem, social activists 'almost always argue that 
victimization is very common, stress that victimization is consequential, and present victimization as relatively straightforward and unambiguous, the victimiser is exploitative, the victim is innocent' (Best 1999 cited in O'Connell Davidson 2011, 458). Accordingly, campaign materials, policy documents, newspaper reports and documentaries lend credence to claims about the vast size of the problem by listing the many abuses and problems football trafficked migrants experience, for example, homelessness, slavery, child prostitution and enforced criminal activity (see Donnelly and Petherick 2004; Haynes 2008; McDougall 2010).

Emphasising the connection between football trafficking and the sex industry serves to reinforce the severity of consequences allied to this practice and to demarcate those involved as either 'victims' (players) or 'villains' (agents/intermediaries). As alluded to by Michel Platini, football trafficking involves children being 'torn' from a seemingly positive or at least neutral environment free from exploitation, and placed in danger. Thus the agency of migrants within popular narratives of football trafficking takes a particular form. The (child) migrant within football trafficking narratives has 'object like been removed, transported and put to use for purposes of exploitation' (O’Connell Davidson 2011, 463).

Salt (2000) notes that trafficking challenges traditional conceptions of migration by blurring the boundaries between forced and voluntary migration movements, and the degree of choice able to be exercised by the migrant. This premise is particularly problematic here, as the underlying preoccupation with minors (those under the age of 18) as evidenced in FIFA's regulations, CFS' 'Ethical Transfer Charter' and broader media coverage, incorporates dominant Western discourses of trafficking that see women and children as victims defined by their innocence and vulnerability to exploitation (Anderson 2007). Thus the notion of an unaccompanied child migrant becomes an oxymoron that disturbs the victim-agency binary. To speak of child migrants is to bring together what are often disparate social categories (O'Connell Davidson 2011).

The young people who become embroiled in football trafficking must likewise be passive victims, whose decision-making skills have been rendered null and void, that is, they must have been trafficked. Consequently, an issue highlighted by several interviewees and at the training camp in Bel-Air was that having technically managed to migrate independently of their parents-deemed indicative of undertaking adultlike responsibilities-they no longer matched the stereotype of a trafficking victim. Furthermore, due to the practice of age falsification amongst West African players in the football industry, their claim to be under 18 years of age was often disputed by French immigration and social services. Gerard's experience was indicative of this situation, having been abandoned by his agent in a hotel on the outskirts of Paris with no identification, he was asked to take a bone test to confirm he was 16 years of age. Attempts were then made to repatriate Gerard; however, when his case was sent for judicial review the judge declared that his documents sent over from Guinea were valid, and he was allowed to remain in Paris indefinitely. 
In a separate case, an agent abandoned an Ivorian migrant named Ismail in a Parisian hotel without taking him to a trial. However, unlike Gerard, despite having no money and documentation Ismail avoided homelessness through a chance meeting with a member of the Ivorian diaspora. The clerk at the hotel where he was abandoned gave him $€ 20$ and advised him to go to La Chappelle, an area known for its large Ivorian community. That same day someone noticed Ismail crying and appearing distressed in a park, the person was an old friend from primary school, who Ismail had not seen nor heard from in over a decade. Ismail stayed with his friend who later took him to social services. Unlike Gerard, he was accepted as a minor and provided with support. Ismail attributed the kindness and advice of the hotel clerk, and the subsequent chance meeting with his former school friend, to placing his faith in a positive outcome in the hands of Allah. ${ }^{7}$

It is clear from Gerard's case that a 'Victim of trafficking' (VoT) or perhaps more specifically a 'Victim of Football Trafficking' (VoFT) is both an administrative category entailing certain state protections and obligations towards individuals, and a descriptive term applied by non-governmental organisations and other civil society actors to people who have certain sets of experiences. Those who fit the descriptive term do not necessarily fall into the administrative category (see also Samers 2003). This placed the young people I met in a predicament. To be offered the rights associated with being a VoFT, they had to meet the administrative category, yet responding to a trafficked person is administratively and financially costly to a destination country (Anderson 2007). Having overstayed their tourist visa and being unable to verify their status as a minor meant that in the eyes French immigration, they were simply male adults staying illegally in Paris.

The transition from having status as a minor to an adult is important because unlike women and children, male adult irregular migrants are often attributed with agency and therefore do not match the category of VoT. They match the category of a smuggled migrant (Nieuwenhuys and Pecoud 2007). Smuggled migrants are not entitled to any of the special protections that states are legally required to make available to VoT and there is no obligation placed on states to consider the human rights of smuggled migrants when repatriating them (Anderson 2007).

Repatriation also becomes an option even if it could not be proven that the person was above 18 years old, but there was evidence that they had been duped. Armand and Adam, two Ivorian migrants, were in this position having been told they had no reason to remain in France when their tourist visas expired (this was also the situation faced by the vast majority of young people I met in Bel-Air). Their tourist visa was invalid given the purpose of their visit. They came under a false premise and would not have migrated had they foreseen this outcome, so the logical solution was to return to their country of origin. This was not considered an acceptable option and they opted to stay in Paris illegally. 


\section{Beyond a Sense of Shame}

Dominant accounts of football trafficking frequently attribute irregular football migrants' disinclination to return to their origin countries to the shame their situation will bring in their country of origin, particularly as family members and the wider community often financed their trip. There is some truth to this claim, as all of the irregular migrants I spoke to in Paris had at one point or another felt ashamed and embarrassed by their situation. Many also suffered from bouts of guilt tied to a belief they had destroyed the lives of family members in their country of origin who had sacrificed to fund their passage abroad. Nevertheless, while narratives of shame are significant and should not be dismissed, their dominant position in accounts of football trafficking tends to obscure discussion about the role of a migrants' family, particularly during the initial decision to migrate. This is not a shortcoming unique to research on irregular football migration. As Carter $(2007,2013)$ notes, although academic interest in sport-related migration is growing, these discussions are limited because they place no interpretative weight on the role of family dynamics. This observation that the family should be moved from the periphery to the foreground in discussions concerning sport-related migration is particularly prescient in the context of football trafficking.

A key theme that emerged during interviews with migrants in Paris and also during interviews with young footballers in Accra was a belief that a career in professional football and migration to a league outside of Africa were now viewed as a viable livelihood strategy to lift an individual and therefore vicariously their family out of poverty (see also Esson 2013; Jua 2003). Pierre, a 17-year-old from Guinea, who was originally abandoned by an intermediary in Portugal and managed to make his way to France explained this point as follows:

Everything turns around football and there isn't a single family in Guinea that doesn't have a son that wasn't pushed to play football, everyone thinks that if a boy is talented he can make it to a league in Europe and money will follow. ${ }^{8}$

The rationales underpinning this situation are not unique to football-related migration. In their overview of historical and contemporary African migration dynamics, Bakewell and De Haas (2007) show how families across the continent use migration as part of strategies to build a better life (see Coe 2012; De Haas 2010). Yet this idea that a career in football and migration to a league outside of Africa are a viable livelihood strategy that has implications specific to football trafficking.

During my time in Accra, I witnessed first-hand how young Ghanaian males' desire to use football as a means to earn an income and help their family financially, alongside their family's eagerness for them to do so, placed considerable pressure on players to do whatever was necessary to secure a trial abroad:

The Pied Piper who leads the children away with their parent's blessing $\ldots$ he is commissioned to take full advantage of the extended family, and of the poor man's assumption that anywhere is better than here. (Astill 2001 cited in Manzo 2005, 397) 
This quote refers to child traffickers and labour exploitation that takes place by abusing the West African practice of 'cultural placement' in Benin, Ghana, Togo, Senegal and Côte d'Ivoire. Traditionally, 'cultural placement' is a reciprocal arrangement whereby a young person leaves his immediate family and is placed in the care of an individual or household, with their labour offered in exchange for education and/ or training, as well as his means of subsistence (Manzo 2005). The former vicepresident of the Ghanaian Football Association (GFA) Jordan Anagblah used an example from his own academy to illustrate how attitudes towards trust underpinning 'cultural placement', and the association between football and opportunities to migrate to the West, create a lethal concoction that places young African footballers in precarious positions. Importantly, the quote also highlights how even the vicepresident of a football association can be rendered powerless to prevent certain practices that are taking place in the West African football milieu:

\begin{abstract}
There was a small boy in my team and the father came and told me somebody is taking him to Belgium. Whether he is going to kill him he doesn't know, but because he has heard football and Europe he thinks his son will make money and be ok. You don't know these people you only met them now in Ghana when they came to watch him play and you say you are giving your boy out for adoption? Nonsense! But it is his child he says the man wants to adopt his son. What can I do?
\end{abstract}

The previous quotes resonate with 'White Man Kontri' discourses, and the associated construction of 'an imagined geography that elides spaces of the West with worlds of material consumption as the basis of an enduring dream' (Nyamnjoh and Page 2002, 628). This perpetuates the idea that travelling to the West leads to social mobility and contributes to what Kalir (2005) terms a 'migratory disposition' to describe the manner in which people develop the desire to leave through experiences of socioeconomic inequality and expressions of wealth connected to migration. CFS is concerned that this belief that 'football + Europe = financial success' is encouraging young African's to place themselves in potentially dangerous situations. Moreover, that this belief is preventing messages depicting the plight of 'VoFT', particularly those remaining in Europe illegally, being heard and taken seriously in origin countries.

It is true that migrants with irregular status living in Europe, or more specifically Paris, do not live an easy or stigma-free existence. As noted by McGregor (2011), the insecurity surrounding one's immigration status 'shapes personal health, the capacity to rebuild private and public domains of life, but also attitudes towards the law, justice, belonging and citizenship' (598). When I finished interviewing Armand and Adam and they offered to walk me to the Metro station, they discussed how even this simple act was fraught with an element of danger. If a police officer were to stop us on the way and ask to see identification, it would not bode well for them. Furthermore, their status made it difficult to play for an established amateur team, let alone build a professional football career. Armand explained how a scout spotted 
him playing in an informal match, however the club refused to sign him due to his immigration status.

Adam and Armand both left Cote d'Ivoire in pursuit of upward social mobility through football, yet they found themselves on a downward trajectory. However they could not share this sense of a less-than-certain future with family members and friends in Cote d'Ivoire. This was not only because of the aforementioned sense of shame but also because on the few occasions they had dared to disclose their plight people were not convinced by their depiction of life in Paris. The following extract from a conversation between Robert, Jules and myself best articulated this point. ${ }^{10}$ Significantly, the quote also draws attention to how alongside narratives of shame there is another reason why migrants remain in destination countries illegally. Life as an undocumented migrant in Europe is more preferable than returning to their country of origin:

\footnotetext{
RT-In Africa they believe like I said that Europe is paradise. Everybody living in Europe is in a good condition. But here you look around you and see people who are really facing difficulties.

INT-So when you tell your family in Cameroon this what do they say?

RT-They don't believe you!

JS-Yes they will ask you, 'why you don't come back'?

RT-They say, 'if it is so hard why do you want to stay there'?

INT-So what do you say?

RT-You are stuck. There is nothing you can say again. They have caught you. They say if things are so difficult then you come back
}

\section{There Is No Place Like Home}

CFS now believes that the regulation of clubs and agents by national football authorities is an ineffective way of preventing football trafficking, as regulation without a serious mechanism to ensure enforcement is meaningless. The Ethical Charter is also considered unlikely to make a noticeable difference, given that it has existed for almost a decade with few willing signatories. Furthermore, spending time and resources lobbying for the improvement of African football in order to reduce the supply of potential irregular migrants is deemed futile. This is not because improving the standard of African football is a futile endeavour. As highlighted by Darby and Solberg (2010), there is evidence to suggest that if the standard of African football were to improve, some players would indeed prefer to stay and play in Africa rather than move abroad. These sentiments were echoed during interviews with Tom Vernon (a former scout for Manchester United FC and founder of the Vodafone Right to Dream Academy) and three executive members of the GFA. Moreover, Anthony Baffoe, a former Ghanaian international football player and the current secretary of the Professional Footballers Association of Ghana, explained how the inability of clubs to pay players a decent salary was encouraging Ghanaian players to emigrate including to countries not traditionally known for their footballing infrastructure, such as India, Bangladesh and Pakistan. 
The problem with attempting to reduce the number of potential irregular migrants by improving the standard of professional football in Africa is that while this this approach may provide a long-term structural solution, it requires significant financial investment and capacity building. CFS does not have the resources to lobby for such investment, let alone based on humanitarian as opposed to commercial rationales. Moreover, this diverts the organizations' limited resources away from helping people in the here and now.

The dissemination of anti-trafficking messages has been at the heart of CFS' work since its inception, however this was not part of an organised policy approach. CFS now proposes that the most effective strategy would be to focus on limiting the supply of potential VoFT through a sustained region-wide anti-trafficking media campaign (TV, radio and print), using high-profile West African players such as Didier Drogba (Cote d'Ivoire), Samuel Eto'o (Cameroon) and Michael Essien (Ghana) to warn young people about football trafficking. ${ }^{11}$ Alongside the regionwide anti-trafficking media campaign, which would include a feature length documentary, CFS is also planning to create information centres in West African countries with staff trained to educate young people and clubs about football transfer regulations.

The use of awareness campaigns to inform potential migrants about the risks associated with irregular forms of migration is an increasingly popular strategy amongst anti-trafficking activists and policy-makers more generally (Andrijasevic and Anderson 2009). Similarly to the arguments put forth by CFS, a key justification of trafficking awareness campaigns lies in the belief that traffickers prosper on the potential migrants' hope of a better life abroad. By raising awareness of the harsh realities of life in destination countries and the risks of migration, false illusions of life, particularly in Europe, can be countered. If young migrants knew what awaited them in destination countries they would change their behaviour accordingly.

Interestingly, participants painted a far more ambivalent picture regarding the feasibility of this strategy. They all without fail suggested that an awareness campaign should take place, yet the effectiveness of such an approach was simultaneously dismissed for the following reasons. First, it was argued that information documenting the risks associated with football trafficking was likely to be ineffectual, as it would be deemed biased. If for example an African VoFT or member of the Diaspora were to return and provide the information, people would assume that it was merely a tactic to prevent them from travelling and 'enjoying the West', as the VoFT presumably had done before they returned.

Participants argued that in order for the proposed information centres to be taken seriously and deemed a legitimate venture, they would need to involve local people residing in their respective African country or white Europeans. Moreover, the use of professional football players to spearhead the campaign was considered even more problematic for the very reason CFS argued they were suitable. Professional football players are rich, powerful and iconic figures in West Africa with the potential to reach 
a wide audience. Yet CFS fails to consider that a key reason why Drogba, Eto'o and Essien are perceived to have attained this success is because they left Africa.

A second reason, as to why information centres and awareness campaigns were likely to be ineffectual, was linked to an erroneous understanding of how young people in West Africa understand risk when making migratory decisions. In awareness campaigns such as those proposed by CFS, risk is imbued with negative connotations and synonymous with danger, yet a more value-neutral interpretation that reflects subjective dispositions is needed. The notion of risk underpinning CFS' planned anti-trafficking campaign results in a preoccupation with wrestling control of future outcomes from fate's clutches and overseeing migrant decision-making in an attempt to alleviate risk. Yet this approach makes little sense in a context where causality is perceived as predetermined by the will of a higher entity and/or invisible supernatural forces that interact with the material world and influence life chances and everyday activities (see also Hernández-Carretero 2009).

It is not therefore a case of risk being inconsequential, rather risk becomes an issue of mediation not avoidance (Hernández-Carretero and Carling 2012). When I asked participants whether more information detailing the risks associated with football migration particularly instances of football trafficking would make a noticeable difference, their response was a resounding no. As Jules explains below, someone else's failure has little bearing on the likelihood of your own success, particularly if one believes in a higher power or entity, as for example Ismail did when he was abandoned:

\begin{abstract}
No, no, no it won't really make a difference [more information]. The way it is is that everybody thinks that success is something that belongs to them and they can succeed and they will have their own luck. You can see somebody fail but you don't stop just because somebody else failed. You say ok, yes that person failed but me I have my chance and with God's help I will make it. ${ }^{12}$
\end{abstract}

The interplay between migrant agency, structural and collective factors and risk also emerged during interviews with young people in Accra. A particularly noteworthy interview involved a 30-year-old Nigerian footballer called Yusuf. Yusuf came to Accra in 2009 after borrowing money from relatives to pay a football 'agent' US $\$ 3000$ to secure a playing contract at a Ghanaian premier division club, followed by trials for a European team. Unfortunately, when Yusuf arrived in Accra, the agent stopped returning his phone calls and a playing contract never materialised. What kept him going was a conviction that another intermediary would spot him and help secure a transfer to a European football club. When we discussed why Yusuf still held onto this faith in migration through football, he explained in evocative and unequivocal terms how this was his method for actualizing escape from Africa:

If you are in a dark room and just in the corner you can see some small light you will take yourself to the light to try to see. For us players we see these agents as a light to take us from the darkness. The agents give us hope of getting out [of Africa]. ${ }^{13}$ 
Trusting a stranger as part of an attempt to migrate through football may be considered risky; however, the consequences of this risk can be positive or negative. It is therefore not risk-taking itself, but its possible outcomes that are value-laden and which intertwine with expected outcomes. This is how the West African youth I encountered in Paris and Accra understood football migration. If migrating through football was indeed a risk, it was a risk worth taking in light of their socio-economic situation and the feasibility of alternative options to migrate and attain social mobility. This was a key reason how one person (agent/intermediary) was able to exercise and abuse power over another person (player), which as noted by Anderson (2007), is key to the mobilisation of potential irregular migrants. Gerard articulated this point as follows:

In Guinea there are so many people who want to leave and think playing football is a way out, but someone needs to come and see you and take you out of that situation. It is like you have all of these prisoners and no lawyer, but if a lawyer comes everyone wants the lawyer because it is the only way out. In prison the people who have money can hire a lawyer and the next day they are out, but the people who are innocent and thrown into prison but don't have money just sit there and hope someone will come. ${ }^{14}$

The preceding quotes draw attention to an important but often ignored issue. Football trafficking awareness campaigns and the other policies designed to prevent this form of irregular migration associate success with the attainment of a secure football contract and allowing minors to migrate safely or not at all. Yet for the migrants I encountered, making it out of West Africa to Europe is also a form of success, all though often of a pyrrhic nature. To be clear, I am not justifying the practices of the intermediaries who prosper from exploiting football migrants. As discussed above, these intermediaries cause considerable harm and damage to the lives of migrants and their families. However, as also touched upon in the discussion above, a key outcome of the acts perpetrated by these intermediaries corresponds with the underlying desire of the young people they exploit. They ended up in Europe. This is a key factor in the effectiveness of football trafficking. If attempting to migrate through football is indeed a risk, it is one African youth deem worth taking in order to be spatially mobile and overcome the uncertainty and constraints on life ambitions facing them in West Africa.

\section{Conclusions}

This article used the issue of football trafficking to show how stepping away from the relatively fixed moral terrain of sex-related trafficking complicates how migrants are conceptualised and treated in a destination country. I argued that by ignoring migrant subjectivity and the cultural meanings associated with spatial mobility, existing policy responses frame irregular football migrants as being better off at home'. This position is in accordance with broader practices within the immigration and social services systems in destination countries, which often construe repatriation 
as the logical solution to their situation. Problematically a tension emerges because for many of these irregular football migrants their country of origin is precisely where they do not want to be. This tension is one of the key reasons why policy responses are unlikely to deter prospective migrants from attempting to migrate through football.

By avoiding broader understandings of the young people involved in football trafficking, the conclusions of policy-makers and activists are inadvertently reductive. Consequently, existing policies circumvent the possibility that the young people embroiled in irregular forms of football migration are not seeking to migrate for purely football-related reasons. Moreover, they ignore how the interplay between a desire to enjoy the living standards associated with the West, and an awareness of constraints on their ability to do so, opens a window for the imposition of unfavourable transfer and travel conditions to emerge.

This counter narrative to popular accounts of football trafficking is perhaps unsettling for some readers, as it could be argued that I implicate the migrant in the process by bringing their agency and subjectivity to the fore. If we step back and attempt to think through why this is unsettling, it encourages us to recognise that a process of abstraction is taking place when we conceptualise football trafficking. This abstraction requires that the migrant takes a specific form, a form that does not disturb the victim-criminal binary that underpins dominant football trafficking discourses. It is this process of abstraction that seeks to mould an irregular football migrant to meet the administrative criteria of a trafficked migrant, and in doing so, binds subjects together and disregards the wider socio-economic context and subjectivities underpinning their migration. This diverts policy-makers' attention away from how in an era of globalisation characterised by ever-expanding connection and communication, there is also an ever-expanding prominence of walls, borders and high technologies of social exclusion (Anderson, Sharma, and Wright 2009; Bakewell 2008; Ferguson 2006). Consequently, if attempting to migrate through football is indeed a risk, it is one African youth deem worth taking considering their limited options to legitimately gain entry to European countries, and attain the spatial and thus social mobility they so desperately crave.

\section{Acknowledgements}

I would like to express my gratitude to all the research participants who took part in this study. I am particularly grateful to staff at CFS for their assistance during my fieldwork. Many thanks also to JoAnn McGregor, Claire Dwyer, Ben Page and the anonymous referees for their comments and suggestions.

\section{Funding}

The Economic and Social Research Council funded this doctoral research. 


\section{Notes}

[1] For security reasons, I have used an alternative location. The names of participants and clubs are pseudonyms. All other names are genuine unless stated otherwise.

[2] Extracts from the interview with Gerard 12 July 2011 (Guinean).

[3] Darby, Akindes, and Kirwin (2007), European Commission White Paper on Sport (2007), ECS (2009), Poli (2010b) and Simons (2010).

[4] At the time, regulated in Article 12(a) of the 2001 FIFA RSTP, which formed the basis for Article 19 of the 2005, FIFA RSTP which was revised in Article 19 of the 2009 FIFA RSTP.

[5] Presentation by Jean-Claude Mbvoumin 6 March 2012-Birkbeck College, University of London.

[6] Interview with Robert 10 July 2011 (Cameroonian).

[7] Interview with Ismail 24 July 2011 (Ivorian).

[8] Interview with Pierre 27 July 2011 (Guinean).

[9] Interview with Jordan Anagblah 29 March 2011-GFA Accra.

[10] Interview with Jules (Cameroonian) and interview with Robert (Cameroonian) 10 July 2011-Paris.

[11] Interview with Jean-Claude Mbvoumin 6 July 2011-CFS and Presentation by Jean-Claude Mbvoumin 6 March 2012-Birkbeck College, University of London.

[12] Interview with Jules (Cameroonian) 10 July 2011-Paris.

[13] Interview with Yusuf (Nigerian) 20 February 2011-Accra.

[14] Interview with Gerard (Guinean) 12 July 2011-Paris.

\section{References}

Alegi, P. 2010. African Soccerscapes: How a Continent Changed the World's Game. London: C Hurst \& Co Publishers.

Anderson, B. 2007. "Motherhood, Apple Pie and Slavery: Reflections on Trafficking Debates." Centre on Migration, Policy and Society Working Paper No. 48, University of Oxford. http:// www.compas.ox.ac.uk/publications/Working\%20papers/Bridget\%20Anderson\%20WP0748.pdf.

Anderson, B., and R. Andrijasevic. 2008. "Sex, Slaves and Citizens: The Politics of Anti-trafficking." Soundings 40: 135-145.

Anderson, B., N. Sharma, and C. Wright. 2009. "Editorial: Why No Borders?" Refuge 26 (2): 5-18.

Andrijasevic, R., and B. Anderson. 2009. "Anti-trafficking Campaigns: Decent? Honest? Truthful?" Feminist Review 92 (1): 151-155. doi:10.1057/fr.2009.1.

Bale, J. 2004. "Three Geographies of African Football Migration.” In Football in Africa, edited by G. Armstrong and R. Giulianotti, 229-246. London: Palgrave Macmillan.

Bakewell, O. 2008. "Keeping Them in Their Place': The Ambivalent Relationship between Development and Migration in Africa." Third World Quarterly 29 (7): 1341-1358. doi:10.1080/01436590802386492.

Bakewell, O., and H. De Haas. 2007. "African Migrations: Continuities, Discontinuities and Recent Transformations." In African Alternatives, edited by P. Chabal, U. Engel, and L. De Haan, 95-118. Leiden: Brill.

Bennhold, K. 2006. "Soccer Dreams and Reality." Play the Game. http://www.playthegame.org/ knowledge-bank/articles/soccer-dreams-and-reality-1026.html.

Carter, T. F. 2007. "Family Networks, State Interventions and the Experience of Cuban Transnational Sport Migration." International Review for the Sociology of Sport 42 (4): 371-389. doi:10.1177/1012690208089832.

Carter, T. F. 2013. "Re-placing Sport Migrants: Moving beyond the Institutional Structures Informing International Sport Migration." International Review for the Sociology of Sport 48 (1): 66-82. doi:10.1177/1012690211429211. 
Coe, C. 2012. "Growing Up and Going Abroad: How Ghanaian Children Imagine Transnational Migration." Journal of Ethnic and Migration Studies 38 (6): 913-931. doi:10.1080/1369183X. 2012.677173.

Darby, P., G. Akindes, and M. Kirwin. 2007. "Football Academies and the Migration of African Football Labor to Europe." Journal of Sport and Social Issues 31 (2): 143-161. doi:10.1177/ 0193723507300481.

Darby, P., and E. Solberg. 2010. "Differing Trajectories: Football Development and Patterns of Player Migration in South Africa and Ghana." Soccer and Society 11 (12): 118-130. doi:10. 1080/14660970903331433.

Davidson, J. O. 2011. "Moving Children? Child Trafficking, Child Migration, and Child Rights." Critical Social Policy 31 (3): 454-477. doi:10.1177/0261018311405014.

De Haas, H. 2010. "Migration and Development: A Theoretical Perspective." International Migration Review 44 (1): 227-264. doi:10.1111/j.1747-7379.2009.00804.x.

Donnelly, P., and L. Petherick. 2004. "Workers' Playtime? Child Labour at the Extremes of the Sporting Spectrum.” Sport in Society 7 (3): 301-321. doi:10.1080/1743043042000291659.

Esson, J. 2013. "A Body and a Dream at a Vital Conjuncture: Ghanaian Youth, Uncertainty and the Allure of Football." Geoforum 47: 84-92. doi:10.1016/j.geoforum.2013.03.011.

European Commission. 2007. "White Paper on Sport." Europa. http://ec.europa.eu/sport/docu ments/wp_on_sport_en.pdf.

European Commission. 2009. "Study on Sports Agents in the European Union." Europa. http://ec. europa.eu/sport/library/doc/f_studiesstudy_on_sports_agents_in_the_EU.pdf.

Ferguson, J. 2006. Global Shadows: Africa in the Neoliberal World Order. Durham and London: Duke University Press

FIFA. 2008. "Regulations Players' Agents.” FIFA. http://www.fifa.com/mm/document/affederation/ administration/51/55/18/players_agents_regulations_2008.pdf.

FIFA. 2010. "Regulations on the Status and Transfer of Players." FIFA. http://www.fifa.com/mm/ document/affederation/administration/01/27/64/30/regulationsstatusandtransfer2010_e.pdf.

FIFA. 2011. "TMS Refresher for Africa." FIFA. http://www.fifa.com/aboutfifa/organisation/football governance/news/newsid=1418243/index.html.

FIFA. 2013. “Transfer Matching System.” FIFA. http://www.fifatms.com/en/Company/Vision-andMission.

Haynes, J. 2008. "Football Trafficking: The New Slave Trade." Modern Ghana News. http://www. modernghana.com/print/159436/2/football-trafficking-the-new-slave-trade.html.

Hernández-Carretero, M. 2009. "Boat Migrants' Perspectives on Risk." Paper presented at The Human Costs of Border Control in the Context of EU Maritime Migration System, Amsterdam, the Netherlands, October 25-27. http://www.rechten.vu.nl/nl/Images/Paper_ Hern\%C3\%A1ndez_Carretero_tcm22-105077.pdf.

Hernández-Carretero, M., and J. Carling. 2012. "Beyond Kamikaze Migrants: Risk Taking in West African Boat Migration to Europe." Human Organization 71 (4): 407-416.

Jua, N. 2003. "Differential Responses to Disappearing Transitional Pathways: Redefining Possibility among Cameroonian Youths.” African Studies Review 46 (2): 13-36. doi:10.2307/1514824.

Kalir, B. 2005. "The Development of a Migratory Disposition: Explaining a 'New Emigration'." International Migration 43 (4): 167-196. doi:10.1111/j.1468-2435.2005.00337.x.

Koser, K. 2010. "Dynamics and Directions of Irregular Migration." Population, Space and Place 16 (3): 181-193.

Langevang, T., and K. V. Gough. 2009. "Surviving through Movement: The Mobility of Urban Youth in Ghana." Social and Cultural Geography 10 (7): 741-756. doi:10.1080/14649360903 205116.

Lindberg, K. 2006. “The Man Who Traced 442 Soccer Slaves." Play the Game. http://www. playthegame.org/upload/magazine,202005. 
Manzo, K. 2005. "Exploiting West Africa's Children: Trafficking, Slavery and Uneven Development." Area 37 (4): 393-401. doi:10.1111/j.1475-4762.2005.00644.x.

McDougall, D. 2008. "The Scandal of Africa's Trafficked Players." The Observer. http://www. guardian.co.uk/football/2008/jan/06/newsstory.sport4.

McDougall, D. 2010. “Traffickers Exploit Africa’s Soccer Dream.” The Sun, June 1.

McGregor, J. 2011. "Contestations and Consequences of Deportability: Hunger Strikes and the Political Agency of Non-citizens." Citizenship Studies 15 (5): 597-611. doi:10.1080/ 13621025.2011.583791.

Nieuwenhuys, C., and A. Pecoud. 2007. "Human Trafficking, Information Campaigns, and Strategies of Migration Control.” American Behavioral Scientist 50 (12): 1674-1695. doi:10. $1177 / 0002764207302474$.

Nyamnjoh, F. B, and B. Page. 2002. "Whiteman Kontri and the Enduring Allure of Modernity among Cameroonian Youth." African Affairs 101 (405): 607-634. doi:10.1093/afraf/101. 405.607.

Poli, R. 2010a. "African Migrants in Asian and European Football: Hopes and Realities." Sport in Society 13 (6): 1001-1011. doi:10.1080/17430437.2010.491269.

Poli, R. 2010b. "The Migrations of African Football Players to Europe: Human Trafficking and Neocolonialism in Question." At Football for Development, Vienna, April. http://www. footballfordevelopment.net/uploads/tx_drblob/storage/Poli_migration-of-African-football-pl ayers_01.pdf.

Salt, J. 2000. "Trafficking and Human Smuggling: A European Perspective." International Migration 38 (3): 31-56. doi:10.1111/1468-2435.00114.

Samers, M. 2003. "Invisible Capitalism: Political Economy and the Regulation of Undocumented Immigration in France." Economy and Society 32 (4): 555-583. doi:10.1080/03085140320001 41701.

Scherrens, J. 2007. "The Muscle Drain of African Football Players to Europe: Trade or trafficking?" Masters Thesis, Karl-Franzens University of Graz.

Sharma, N. 2003. "Travel Agency: A Critique of Anti-trafficking Campaigns." Refuge 21 (3): 53-65.

Simons, R. 2010. "Trafficking in Football: Are Current Regulations Sufficient in the Protection of Minors in Football?" Masters Thesis, University of Tilburg.

Sparre, K. 2007. "Prevention Programme Proposed to Stop Football Trafficking." Play the Game. http://www.playthegame.org/news/detailed/prevention-programme-proposed-to-stop-foot ball-trafficking-1417.html.

Tyldum, G., and A. Brunovskis. 2005. "Describing the Unobserved: Methodological Challenges in Empirical Studies on Human Trafficking." International Migration 43 (1/2): 17-34. doi:10.1111/j.0020-7985.2005.00310.x.

UEFA. 2008. "Platini Urges Action." UEFA. http://www1.uefa.com/magazine/edition=781329/ newsid $=781355 /$. 